\title{
THE IMAGE OF THE EAST IN THE WORK OF THE MODERN RUSSIAN-SPEAKING WRITER DINA RUBINA
}

\section{Okhida Bakhtiyarovna Yuldasheva}

Lecturer, Department Of Russian Literary Studies, National University Of Uzbekistan Named After Mirzo Ulugbek, Tashkent, Uzbekistan

\section{ABSTRACT}

The purpose of this article is to analyze the image of the East in the work of Dina Rubina on the example of the story "Babka". The theme of the East has become one of the important themes of the work of the famous writer Dina Rubina, who found her special reflection in the novel "On the sunny side of the Street", in the stories "Babka”, "Gypsy", "Killer".

KEYWORDS: - Image, story, hero, motive, composition.

\section{INTRODUCTION}

Interest in the work of Dina Rubina exhausted due to the depth of the themes and conflicts covered in her works, many of which, of course, raised by writers more than once. Nevertheless, it was on the pages of D. Rubina's works that they sounded with new force: the theme of war and peace, the theme of Jewish life. The theme of the continuation of the individual in the history of the family, the theme of national identity, and the theme of the East - the main ideological and thematic platform of Rubina's works.

The story "Babka" is one of the most interesting stories by Dina Rubina, imbued with childhood memories of the Tashkent period of Babka Rachel's life.

The title character of the story is Rachel Koganovskaya, presented through the eyes of her granddaughter of the author-narrator. The title of the story is quite obvious: babka is the main person in the fate of the writer, who made a huge contribution to the education of his granddaughter, and according to the author's own admission that it was she, babka, "...was the first unobtrusive style consultant for me" [5, p.2] the meaning of the title becomes clear. The author describes the difficult fate of Grandmother Rachel: during the war, she went through three evacuations "through the Caucasus and Kazakhstan" and delivered to Tashkent. The image of the grandmother was 
CURRENT RESEARCH JOURNAL OF PHILOLOGICAL SCIENCES 2(9): 25-28,

September 2021

DOI: https://doi.org/10.37547/philological-crjps-02-09-06

ISSN 2767-3758

(C)2021 Master Journals

Crossref doi

gil Google

Accepted20 ${ }^{\text {th }}$ September, 2021 \& Published 25 ${ }^{\text {th }}$ September, 2021

supplemented by memories that the model Rachel was married had two children and was a homemaker. The author, carefully preserving in memory the talents of the grandmother-inspired singing, artistic representation of various situations, the ability to tell a funny story-lamentably exclaims "...how did you manage to thoughtlessly screw up such an object? Yes, a great actor and, perhaps, a wonderful writer died in it!" [5, p. 3]. The author cites in the text Babkin's wonderful parables, small stories-anecdotes, instructing stories, transmitting, which were truly a storehouse of folk wisdom and for the author is childish imagination, moments of wonderful stories and became, apparently, the impetus for word making.

The story takes place in old Tashkent: "It was already other times and other lands: not the fertile pre-war Ukraine, but the sultry pandemonium of adobe Tashkent, where-through the Caucasus and Kazakhstan - my relatives were evacuated at the beginning of the war and where they were stuck forever..." [5, p.3], but at the very beginning of the story, the author takes the reader to Ukraine, where the maternity hospital is almost all the relatives of the hero: "The photographer of the town of Zolotonosha had a sublime passion for art..." [5, p. $1]$, so it initially becomes clear that the actions in the conditionally present Tashkent and in the past Ukraine will be interspersed with each other through flashbacks. Thus, the image of Tashkent becomes one of the main images in the work of art. In this passage describing the house on Kashgark: "But this house in a large, full of children in the Tashkent courtyard on Kashgark. The most Babylonian, most multi - lingual area of the huge city rammed by the evacuation, this adobe house: a room and a kitchen opening onto a large veranda covered with old vines-did not belong to my grandparents, but to my uncle's second wife" [5, p.4]. The author quite reliably depicted the situation in wartime and the post-war period, when the hospitable and diverse Tashkent sheltered thousands of orphaned children of different nations. For which, later, in many works, he was awarded the paraphrase "bread city", "city of Friendship", etc. It becomes clear that the hero has the warmest and kindest associations with Tashkent. No, wonder the word "Kashgar" in the common people of Kashgar, in translation from the Kyrgyz language means "cashmere", and the meaning of the word takes on softness, warmth.

Note that the first lesson of creativity the author received lying on a tapchan with her grandmother in an ordinary Tashkent house "... adobe shacks, made after the war in a hurry..." [5, p.3] and watching a burning candle, imagined the struggle of the elements with time and drew conclusions: "... create the world with fire, mold it from scalding hot flesh-it's too late to change when it freezes..." [5, p.4]. Therefore, the adobe shacks of Tashkent gave the writer those unforgettable moments of childhood that she cannot forget. In the text, we also see a reference to the historical events of the city: "So, at the end of my life, after the famous earthquake completely changed the appearance of Tashkent and in the center of it grew areas of faceless new buildings, in one of which my uncle and his third, final wife got an apartment..." [5, p.6]. Alai Bazaar is one of the most famous bazaars in Tashkent, which served not only as a market, but also as a place where people could just walk around; communicate with each other, where circus performers could arrange a show of acrobatic gestures. Where they could easily set up a tent with small animals, so that people, interested, jumped into a tent screaming with various screams, where the pleasant smell of freshly prepared shish kebab intoxicated people. Therefore, in the story, the Alai bazaar is a refrain and connects the characters. Fragments of his tragedy are associated with the memories of his grandfather Sender: "And exactly: after learning to walk on prosthetics, he returned to 
CURRENT RESEARCH JOURNAL OF PHILOLOGICAL SCIENCES 2(9): 25-28,

September 2021

DOI: https://doi.org/10.37547/philological-crjps-02-09-06

ISSN 2767-3758

(C)2021 Master Journals

Crossref do

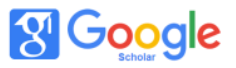

Accepted20 $0^{\text {th }}$ September, 2021 \& Published 25 $5^{\text {th }}$ September, 2021

the butcher's shop in the Alai bazaar and stood on those prosthetics all day, butchering carcasses". The hero's brother is a broken-down person who cuts through the streets of Tashkent at the breakneck speed of a bicycle: "...and he will roll further, further-to Alaysky, to Engels, to Pervomayskaya..." [5, p.4], Babka's entertaining stories always began with the words: "I am going to Alaysky today... the grandmother began slowly, concentrating on stirring the porridge in my plate with a spoon" [5, p.3] - they promise to be interesting, rich, bright and original.

The author fondly recalls the days spent in Tashkent: "My memory so comfortably lived these weeks, winter and summer, lived in Kashgarka, in a house with a single, but large window, radiant as a screen in a rapidly fading cinema hall. In spring and summer, it was full of gloomy poplar foliage..." [5, p. 7]. Here, the memory of the window seems symbolic to us, as if the author learns to look at the world through this window, to understand the laws of life. This understanding is also facilitated by the mention of a candle, the fire of which fought with the element called "time": "Why does the fiery moth of a thinning candle still beckon me in that old, almost indistinguishable window, where the leaves of the beginning of my life still flutter with bird's wings?"

One of the important episodes in the story is the mention of a Muslim cemetery, where the hero once spent almost all day. However, Mamele was not at all afraid of the cemetery crescents and earthen graveyards; she even confused by the sultry silence: "I was lying in the weeping tent of an old willow tree, under a large purple hole, like a window; in it the faint stars still flashed sharply, gradually heating up, swarming and circling..." [5, p. 4]. The situation itself is symbolic: the hero finds herself in a cemetery, a place deserted and terrible, but the Muslim cemetery "embraced" the hero, hid her, kept her in the cradle of a weeping willow. "Cut through" a window to the sky and took her into an extraordinary trance, did not allow her to awaken an unpleasant feeling of loneliness. Fear of incomprehensible rustles and sounds, "...but the ringing and whispering of a summer day and a window full of stars in the dark crown of a lonely willow have since forever merged in my memory with the old Muslim cemetery..." [5, p.6]. In the story, a red thread runs through the motif of memory, which is a kind of framework for the entire work. When describing the two mausoleums, the hero recalls the chipped azure tiles around the mausoleum and "... only a fragment of the latter stuck to the old clay tightly..." [5, p. 5], thus we compare this mentioned fragment with the memory of the author, who, despite "completely different geographical and time slides", sticks to the heroine, which can be correlated with the mausoleum, which has also learned a lot in this life. In addition, the image of Tashkent supplemented by memories of everyday trifles: "I remember in detail the magic junk from the cart "shara-bar", pulled by a drooping donkey: an old Uzbek exchanged clay whistles and tight, ruddy-colored balls blown out of pharmacy teats for bottles..." [5, p.3], even the Eastern names were remembered very clearly: "Immediately the door slammed in the house farthest from the gate, Sharapat, the third daughter of Uncle Hamid, ran out on the porch, and she screamed shrilly: "Assfucker Vanyushka!" - This meant only one thing: the driver Vanyushka brought coal" [5, p.3]. In the memory of the hero, there are such moments that the reader can imagine the Eastern national color.

Thus, after analyzing the story of Dina Rubina "Babka", we conclude that the image of the East plays an important role in this work of art. The description of a Tashkent house with a veranda, lovingly described everyday details: tap Chan, where the hero slept with her grandmother, a vine 
CURRENT RESEARCH JOURNAL OF PHILOLOGICAL SCIENCES 2(9): 25-28,

September 2021

DOI: https://doi.org/10.37547/philological-crjps-02-09-06

ISSN 2767-3758

(C2021 Master Journals

\section{Crossref dol 81 Google}

Accepted20 th September, 2021 \& Published 25 $5^{\text {th }}$ September, 2021

that protects from the scorching sun, a windowtheater, through which you could see extraordinary pictures, Uzbek neighbors with Oriental names and their unique funny pronunciation of Russian wordsrecreate the image of the East. In addition, a special role in recreating the image of the East played by the description of the Alai bazaar, the old streets of Tashkent with names that do not exist now. The Muslim cemetery, so correctly outlined with all its crescents, "talking" crickets, the silence of the summer heat, two dilapidated mausoleums with chipped tiles-reflect the national oriental flavor.

\section{REFERENCES}

1. Baltabaeva A. M. Representation of the novel genre in modern literary studies // Foreign languages in Uzbekistan, 2019. https://scholar.google.com/scholar?oi=bibs\&cl uster $=15917692215917662645 \& b \operatorname{bl} \mathrm{I}=1 \& \mathrm{hl}=\mathrm{e}$ $n$

2. Gibraltarskaya O. N. Axiosphere of modern Russian-language literature // Polish Journal of Science. 2021. № 36-2.

3. Egamberdieva G.M. https://cyberleninka.ru/article/n/svoeobraziekontsovki-v-skazkah-i-dastanah.

4. Kamilova S. E. Development of the poetics of the short story genre in Russian and Uzbek literature of the Late twentieth and early twenty-first centuries //Dissertation for the degree of Doctor of Science (DSc) in Philological sciences,

2016.https://scholar.google.ru/scholar?oi=bibs \&cluster $=13939470032695676091 \&$ btnI $=1 \&$ hl $=\mathrm{ru}$

5. Rubina D. Modern prose: Babka. - Moscow, 2011.

6. Yuldasheva 0. B. Stages of the formation of the "Caucasian prisoner" in Russian literature //Science and Education. 2021. № 4-2. https://cyberleninka.ru/article/n/stages-of- the-formation-of-the-caucasian-prisoner-inrussian-literature

7. Yuldasheva O.B. THE DEVELOPMENT OF RUSSIAN-LANGUAGE LITERATURE IN UZBEKISTAN. https://www.elibrary.ru/item.asp?id=4642304 3

8. Yuldasheva O.B. Obraz Vostoka v rasskaze D.Rubinoy «Babka» https://cyberleninka.ru/article/n/obrazvostoka-v-rasskaze-d-rubinoy-babka

9. Fayzieva M.S. From the history of poetics//PHILOLOGY AND LINGUISTICS. International scientific journal. №2 (14) / 2020.

10. Fayzieva M.S. KITE AS A SYMBOL OF FREEDOM (ON EXAMPLE OF KHALED HOSSEINI'S NOVEL "KITE RUNNER")// Scientific bulletin. NamSU 2021/6. 